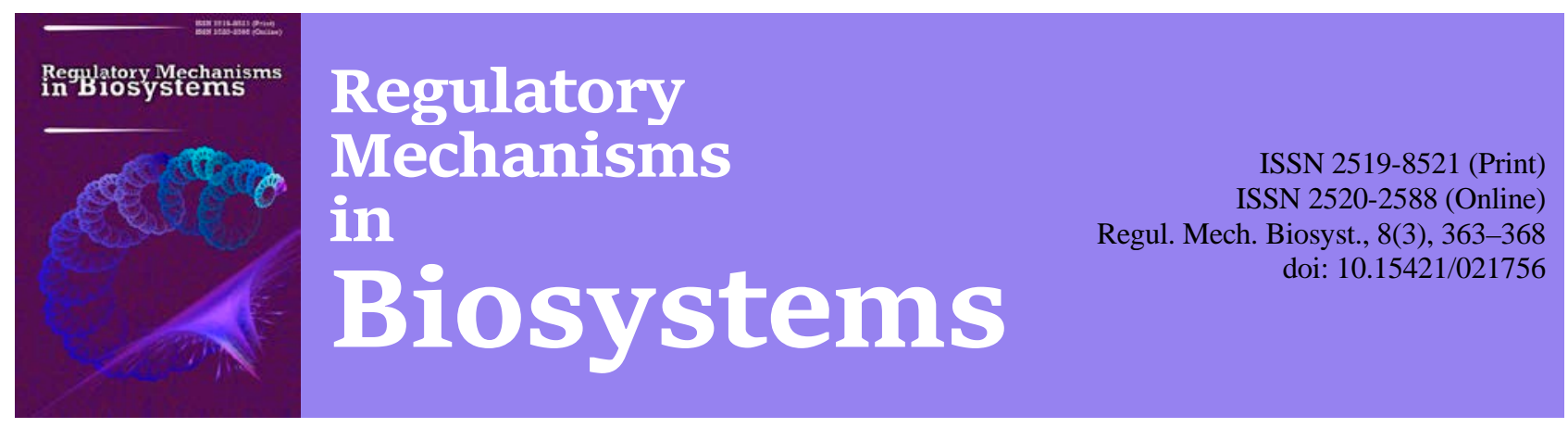

\title{
Morphological and biochemical mechanisms of changes in buccal epithelocytes and erythrocytes in children suffering psycho-emotional stress
}

\author{
R. Z. Gan*, S. L. Popel’** \\ *Ivano-Frankivsk National Medical University, Ivano-Frankivsk, Ukraine \\ **Precarpathian National University named after V. Stefanik, Ivano-Frankivsk, Ukraine
}

Article info

Received 04.07.2017

Received in revised form 29.07.2017

Accepted 04.08.2017

Ivano-Frankivsk National

Medical University,

Galitcka Str., 2,

Ivano-Frankivsk,

76025, Ukraine.

Precarpathian National

University named

after V. Stefanik,

Shevchenko Str., 57,

Ivano-Frankivsk,

76018, Ukraine.

Tel.: +38-097-87-41-446.

E-mail:

popelsergij@gmailcom

Gan, R. Z., \& Popel', S. L. (2017). Morphological and biochemical mechanisms of changes in buccal epithelocytes and erythrocytes in children suffering psycho-emotional stress. Regulatory Mechanisms in Biosystems, 8(3), 363-368. doi: $10.15421 / 021756$

The article provides experimental data on the impact of psychoemotional stress on cytological, morphometric, immunological and biochemical indicators in 7-11 year old children. We examined 100 children of primary school age, who were divided into the main group (50 children who had been resettled from the war zone in Eastern Ukraine) and the control group (50 children, who live in Ivano-Frankivs'k). We used morphological (light-optical and electromicroscopic) and morphometric analysis of buccal epithelium and peripheral blood erythrocytes, biochemical methods for identifying the products of peroxidation of lipids, ceruloplasmin and ferritin according to widely used methods. Morphological methods revealed that under psychoemotional stress, the size of the nuclei and buccal epithelial cells significantly decreases, and their nucleo-cytoplasmic ratio changes towards increase in the share of cytoplasm, and the indicators of coefficient of buccal epithelial cell shape indicate significant deformation of those cells. Similar changes were observed in the erythrocytes of peripheral blood. In the blood, we observed an increase in the $\mathrm{CD}_{95}{ }^{+}$concentration of lymphocytes. Clearly manifested changes in morphological and morphometric indicators of buccal epithelium and erythrocytes when there is an increase in the $\mathrm{CD}_{95}{ }^{+}$level of lymphocytes indicate the development of a systematic apoptosis reaction of the studied cells in the condition of psychoemotional stress. Also we observed clearly manifested changes in the coefficient of erythrocytes' shape, their size and perimeter, increase in the number of reversibly and irreversibly changed cells, which with increase in free radical oxidation, indicates disorders in the organism's antioxidant protection system in general and requires a pathogenically grounded programme of treating complications related to psychoemotional stress among 7-11 year old children who were resettled fom the combat zone in Eastern Ukraine.

Keywords: lipid peroxidation; antioxidant protection; buccal epitheliocytes; erythrocytes; apoptosis

\section{Морфологічні та біохімічні механізми змін букальних епітеліоцитів та еритроцитів у дітей за психоемоційного стресу}

\author{
Р. 3. Ган*, С. Л. Попель** \\ *Івано-Франківський національний медичний університет, Івано-Франківськ, Украӥна \\ **Прикарпатський національний університет імені Василя Стефаника, Івано-Франківськ, Украӥна
}

\begin{abstract}
Наведено експериментальні дані про вплив психоемоційного стресу на цитологічні, морфометричні, імунологічні та біохімічні показники у дітей 7-11 років. Обстежено 100 дітей молодшого шкільного віку, яких поділили на основну групу (50 дітей, переселених із зони бойових дій) і контрольну групу (50 дітей, які постійно проживають у м. Івано-Франківськ). Виконано морфологічні (світлооптичне та електронномікроскопічне) та морфометричне дослідження букального епітелію та еритроцитів периферійної крові, біохімічне виявлення продуктів перекисного окиснення ліпідів, церулоплазміну та феритину за загальноприйнятими методами. Морфологічними методами дослідження встановлено, що за психоемоційного стресу площа ядер і цитоплазми букальних епітеліоцитів значно зменшується, а їх ядерно-цитоплазматичне співвідношення змінюється на користь частки цитоплазми, при цьому показники коефіцієнта форми букальних епітеліоцитів вказують на значну деформованість цих клітин. Подібні зміни відбуваються в еритроцитах периферійної крові. У крові спостерігається збільшення концентрації $\mathrm{CD}_{95}{ }^{+}$лімфоцитів. Виражені зміни морфологічних і морфометричних показників букального епітелію та еритроцитів за збільшення рівня $\mathrm{CD}_{95}{ }^{+}$лімфоцитів вказують на розвиток системної реакції апоптозу вивчених клітин за психоемоційного стресу. При цьому спостерігаються виражені зміни коефіцієнта форми еритроцитів, їх площі та периметра, підвищується кількість зворотно- та незворотно змінених клітин, що на тлі посилення вільнорадикального окиснення свідчить про порушення антиоксидантної системи захисту організму в цілому та потребує патогенетично обгрунтованої програми лікування ускладнень, пов'язаних із психоемоційним стресом у дітей 7-11 років, які були вимушено переселені із зони ведення бойових дій на Сході України.
\end{abstract}

Ключові слова: перекисне окиснення ліпідів; антиоксидантний захист; букальні епітеліоцити; еритроцити; апоптоз 


\section{Вступ}

За психоемоційного стресу в різних тканинах виявляються глибокі біохімічні порушення та зменшення кількості дезінтоксикантів, що зумовлює активацію процесів цитолізу (Gloire et al., 2008; Ahmad et al., 2011). Внутрішньотканинна гіпоксія супроводжує психоемоційні реакції різної етіології та часто проявляється на слизових оболонках. Особливо чутливі до гіпоксії поверхневі епітеліоцити. Аналізуючи стан епітеліоцитів, дослідники цитологічного матеріалу часто обмежують їх вивчення за рахунок оцінювання некрозозапальної активності за системою Metavir і встановлення індексу гістологічної активності запального процесу за Knodell (Godin et al., 2009). Зовсім незначна кількість праць стосується отримання даних, які базуються на доказових морфометричних методах, що дозволяє дати об'єктивну оцінку стану букальних епітеліоцитів у різноманітній патологічній i, що важливіше, на нашу думку, передпатологічній ситуації. Зокрема, останніми роками окремі автори провели подібні спроби під час визначення площі ядер епітеліоцитів і подали об'єктивну оцінку цього показника за різних станів організму (Moscicka-Studzinska et al., 2009; Nikolovski et al., 2017).

На думку Sundaramoorthy et al. (2016) i Zotti et al. (2016), наявність різних передпатологічних і патологічних процесів, у тому числі цитолітичних, безпосередньо відображається на структурі мембрани еритроцитів. За психоемоційного стресу відбувається каскад функціональних змін, які відображаються на різному рівні організації живої матерії. Водночас за таких умов багато авторів виявили активацію процесів перекисного окиснення ліпідів і зниження функцій системи антиоксидантного захисту (Swanepoel et al., 2011; Das et al., 2012). Окремі автори вказують на перебільшення удвічі - утричі вмісту малонового діальдегіду за такого стану. У свою чергу, Gloire et al. (2008) i Choi (2016) вказують, що гіпоксія - один 3 основних факторів запуску процесів апоптозу. Однак ці дані потребують уточнення, що визначило актуальність нашого дослідження.

Мета цього дослідження - охарактеризувати морфологічні та морфометричні зміни букальних епітеліоцитів та еритроцитів на тлі визначення рівня $\mathrm{CD}_{95}{ }^{+}$лімфоцитів і процесів перекисного окиснення ліпідів за психоемоційного стресу в дітей 7-11 років.

\section{Матеріал і методи досліджень}

Обстежено 50 дітей віком 7-11 років, переселених на Прикарпаття із зони бойових дій на Сході України. В усіх дітей під час клініко-психологічного обстеження спостерігали ознаки психоемоційного стресу. Ці діти віднесені до основної групи обстеження. Контрольну групу складають 50 практично здорових дітей цього віку, які проживають постійно в м. ІваноФранківськ і яким проводили обстеження в межах профілактичного огляду в організованих дитячих колективах.

Цитологічний аналіз букальних епітеліоцитів у кількості 500 одноядерних клітин проводили на мікроскопі Leica CME за допомогою аналізатора зображень (відеокамера Sony ExwaveHad SSC-DC58AP). Морфометричне дослідження проводили 3 використанням бази програмного забезпечення UTHSCSA Image Tool ${ }^{\circledR}$ (Mishra et al., 2017). Для цього готували цитологічні препарати-відбитки щічної поверхні слизової оболонки порожнини рота та забарвлювали їх за Романовським - Гімза за рекомендаціями Tredoux et al. (2015) i Klegarth (2017). Визначали такі морфометричні показники епітеліоцитів як площа профілю цілої клітини та ії ядра, співвідношення між площею профілю епітеліоцита та профілем іії ядра, коефіцієнт форми епітеліоцита та його ядра (Moscicka-Studzinska et al., 2009).

Морфофункціональний стан не менше ніж 300 еритроцитів у дітей оцінювали на мазках, забарвлених за Романовським Гімза. Аналіз проводили за такими морфометричними показниками: площа, периметр профілю, коефіцієнт форми.
Різні види деформації еритроцитів виявляли за допомогою сканувального електронного мікроскопа JEOL-25M-T220A (Японія). Препарати крові для сканувальної електронної мікроскопії готували загальноприйнятим методом.

Стан процесів перекисного окиснення ліпідів оцінювали за кількістю малонового діальдегіду, активність каталази, трансферин і церулоплазмін визначали з урахуванням рекомендацій Godin (2009).

У дітей у тесті імунофлуоресценції визначали фенотип лімфоцитів периферійної крові за ідентифікацією диференційованих антигенів із застосуванням моноклональних антитіл, які належать до кластера диференціації $\mathrm{CD}_{95}{ }^{+}\left(\mathrm{Fas} / \mathrm{CD}_{95}\right)$ - апоптозу лімфоцитів (Debatin et al., 2009; Choi, 2016).

Для оцінювання ступеня вірогідності результатів дослідження проводили варіаційний аналіз отриманих результатів. Усі кількісні показники наведені у вигляді $\mathrm{M} \pm \mathrm{m}$, де $\mathrm{M}-$ середне арифметичне, $\mathrm{m}$ - похибка середнього арифметичного. Вірогідність різниці визначали після перевірки на нормальність розподілу за t-критерієм Стьюдента. Кореляційний аналіз проводили за допомогою коефіцієнта кореляції Пірсона.

\section{Результати}

На цитологічних препаратах виявили деструктивні зміни епітеліоцитів (рис. 1). У багатьох епітеліоцитах виявлено процеси, які свідчать про гідропічну дистрофію. В окремих мікропрепаратах зустрічається незначна кількість епітеліоцитів, в ядрах яких виявляються глибки конденсованого хроматину 3 маргінальним розташуванням. При цьому повністю збережена цілісність ядерної оболонки. Цитоплазма в таких епітеліоцитах ущільнена. У деяких епітеліоцитах визначаються великі ацидофільні гранули.

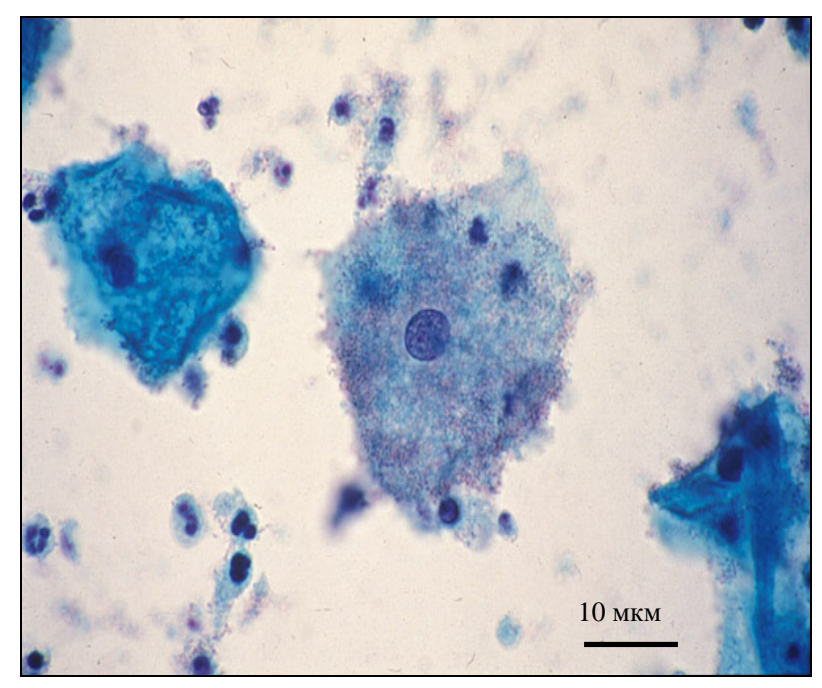

Рис. 1. Цитологічна картина букального епітелію у дітей основної групи з вираженими ознаками психоемоційного стресу

Під час морфометричного дослідження виявлено зменшення середньої площі профілю цитоплазми епітеліоцитів та їх ядер на $17,5 \%$ (відповідно $31,49 \pm 0,03$ мкм $^{2}$ у контрольній групі дітей до $1,23 \pm 0,01$ мкм $^{2}$ в основній групі $(\mathrm{P}<0,05)$. Це причина збільшення співвідношення між площею цитоплазми букальних епітеліоцитів та їх ядер, що досягає в основній групі дітей $0,19 \pm 0,003(\mathrm{P}<0,05)$. Збільшення коефіцієнта форми епітеліоцитів та їх ядер відповідно до 1,25 $\pm 0,07(\mathrm{P}<0,05)$ i $1,18 \pm 0,06(\mathrm{P}<0,05)$ свідчить про те, що їх контури стають менш округлими та більш нерівномірними. Наведені середні показники оцінюють стан букальних епітеліоцитів загалом. Розглядаючи зокрема представництво букальних епітеліоцитів iз різним метричним розподілом їх площі, ми зауважили, що найбільша кількість із них $(77,9 \%)$ має площу 80-160 мкм², тоді як у дітей контрольної групи вона становить 100-250 мкм² 
(85,6\%) (рис. 2). Приблизно такі ж співвідношення встановлені під час визначення площі ядра (рис. 3). 85,4\% ядер мають площу 15-30 мкм ${ }^{2}$ (у дітей контрольної групи - 78,5\% клітин мають ядра площею 20-50 мкм²). Під час психоемоційного стресу гістограма розподілу співвідношення площі ядра до площі клітини дещо зміщується вправо. При цьому величина піків зменшується, але з'являється більше клітин із високими значеннями цього показника (рис. 4). Коливання досягають 0,05 $0,30(77,8 \%)$, тоді як у дітей контрольної групи вони становлять 0,10-0,30 (66,6\%). Контури епітеліоцитів змінюються в напрямку збільшення кількості деформованих клітин, про що свідчить метричний перерозподіл клітин: різко зменшується кількість клітин із найнижчими значеннями коефіцієнта форми, на третину збільшується відсоток клітин величиною 1,20-1,39, учетверо клітин зі значенням коефіцієнта форми 1,40-1,59 і з'являється популяція клітин із вищими значеннями коефіцієнта форми (рис. 5). При цьому певна кількість клітин деформована та має коефіцієнт форми 1,70-2,39 (7,4\%). Таких клітин у дітей контрольної групи не виявлено, а під час психоемоційного стресу показник їх коефіцієнта форми перебільшує 1,80.

Форма ядра також виявляє значну деформацію (рис. 6), що характеризується збільшенням коефіцієнта форми 3 1,30 до 1,59 (у дітей контрольної групи - не більше 1,29).

У дітей основної групи під час психоемоційного стресу площа еритроцитів зменшується до 40,1 $\pm 0,43$ мкм $^{2}$ (у контрольній групі вона становить $-47,4 \pm 0,26$ мкм $\left.^{2}, \mathrm{P}<0,05\right)$. При цьому в основній групі дітей прослідковується морфометричний перерозподіл еритроцитів, оскільки переважають клітини загальною площею 35,2-55,3 мкм².

Периметр еритроцитів зменшується до $24,2 \pm 0,16$ мкм і 89,4\% усіх еритроцитів мають периметр 21,8-25,2 мкм, тоді як у дітей контрольної групи цей показник становить 22,6-30,9 мкм.

Серед еритроцитів найбільші відхилення спостерігаються за показником коефіцієнта їх форми: у середньому він значно знижується до 1,04 \pm 0,002 (у контрольній групі його значення становлять $1,10 \pm 0,003, \mathrm{P}<0,05)$.

При цьому пік гістограми розподілу еритроцитів за показником форми у дітей під час психоемоційного стресу перебуває в межах 1,10-1,15 (58,1\% усіх еритроцитів, тоді як у контрольній групі такі еритроцити виявляються тільки в 9,6\%).

До того ж у 91,4\% дітей контрольної групи достатньо багато еритроцитів мають цей показник у діапазоні 0,95-1,05 $(\mathrm{P}<0,05)$, а під час психоемоційного стресу $(89,3 \%$ дітей основної групи) - лише $0,91(\mathrm{P}<0,05)$.

Водночас, під час визначення стану процесів ПОЛ та АОСЗ установлено, що у цих самих дітей за психоемоційного стресу вміст малонового діальдегіду підвищується до $6,36 \pm$ 0,02 нмоль/л (у контрольній групі цей показник становить тільки 3,86 $\pm 0,02$ нмоль/л), тобто за психоемоційного стресу його рівень збільшується в 1,64 раза $(\mathrm{P}<0,05)$. При цьому концентрація каталази у дітей за психоемоційного стресу також підвищується до 75,4 $\pm 3,3$ мг $\mathrm{H}_{2} \mathrm{O}_{2} /$ л (у контрольній групі цей показник становить тільки $66,1 \pm 2,5$ мг $\mathrm{H}_{2} \mathrm{O}_{2} /$ л, $\left.\mathrm{P}<0,05\right)$. У дітей основної групи під час психоемоційного стресу значно зменшується вміст церулоплазміну та трансферину (відповідно до $10,11 \pm 0,17$ і $0,19 \pm 0,003$ ммоль/л; у дітей контрольної групи ці показники становлять, відповідно, 28,95 $\pm 0,81$ та 0,26 $\pm 0,002$ ммоль/л, $\mathrm{P}<0,05)$. На такому фоні біохімічних показників у дітей основної групи відбувається деформація еритроцитів і зменшення їх площі та периметра (рис. 7).

За психоемоційного стресу у дітей основної групи рівень $\mathrm{CD}_{95}{ }^{+}$лімфоцитів різко збільшувався до 7,1 $\pm 0,33(\mathrm{P}<0,05)$, тоді як у контрольній групі він становить лише 2,17 $\pm 0,23$ (табл.).

Дані про співвідношення антиоксидантної системи до рівня $\mathrm{CD}_{95}{ }^{+}$лімфоцитів у дітей основної групи (рис. 8) вказують на існування прямого кореляційного зв'язку між концентрацією малонового діальдегіду $(\mathrm{r}=0,78)$ та каталази $(\mathrm{r}=0,75)$ та середнього оберненого кореляційного зв'язку між цими показниками та вмістом церулоплазміну $(\mathrm{r}=-0,45)$ та трансферину $(\mathrm{r}=-0,45)$.

\section{Обговорення}

У процесі морфологічного дослідження виявлено порушення форми клітин букального епітелію та їх ядер, що характерно для першої стадії апоптозу (Nikolovski et al., 2017). Із даних літератури (Mishra et al., 2017) відомо, що зміна форми клітини та іiі ядра, а також наявність ацидофільних гранул свідчать про апоптоз, тому що за некрозу у клітинних мембранах (зокрема, ядра та клітинній оболонці) відбувається деструктивні зміни іншого характеру.



Рис. 2. Гістограма розподілу площі десквамованих букальних епітеліоцитів $\left(\right.$ мкм $\left.^{2}\right)$ у дітей контрольної $(\mathrm{n}=50)$ та основної груп $(\mathrm{n}=50)$

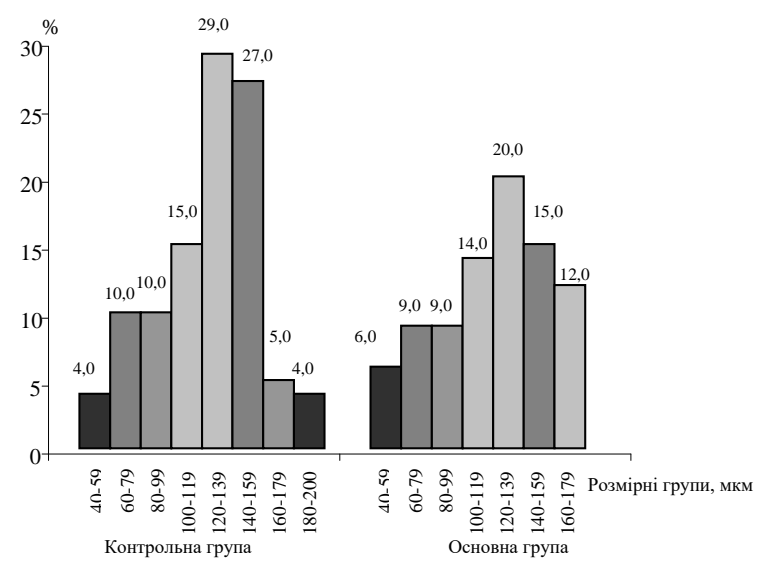

Рис. 3. Гістограма розподілу величини площі ядра десквамованих букальних епітеліоцитів (мкм²) у дітей контрольної $(\mathrm{n}=50)$ та основної груп $(\mathrm{n}=50)$



Рис. 4. Гістограма розподілу співвідношення площі ядра та цитоплазми десквамованих букальних епітеліоцитів $\left(\right.$ мкм² $\left.^{2}\right)$ у дітей контрольної $(\mathrm{n}=50)$ та основної груп $(\mathrm{n}=50)$ 


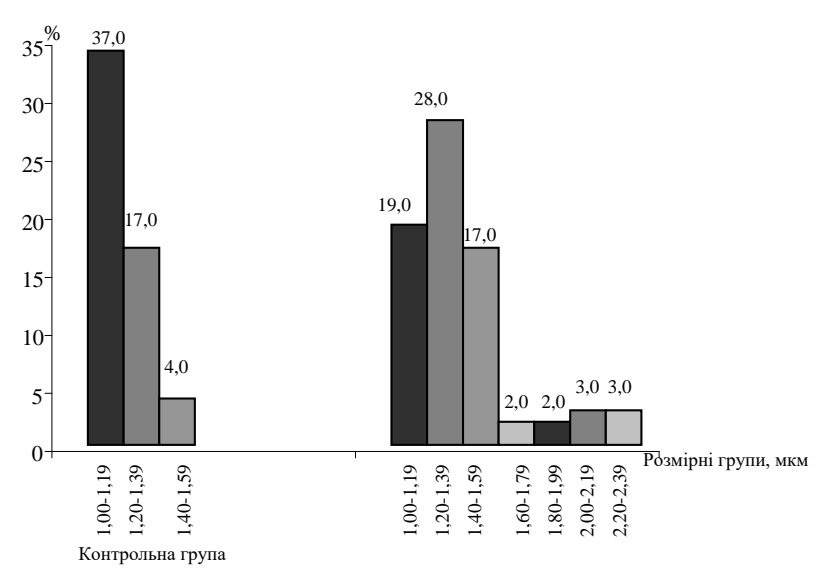

Рис. 5. Гістограма розподілу коефіцієнта форми десквамованих букальних епітеліоцитів (мкм²) у дітей контрольної $(\mathrm{n}=50)$ та основної групи $(\mathrm{n}=50)$

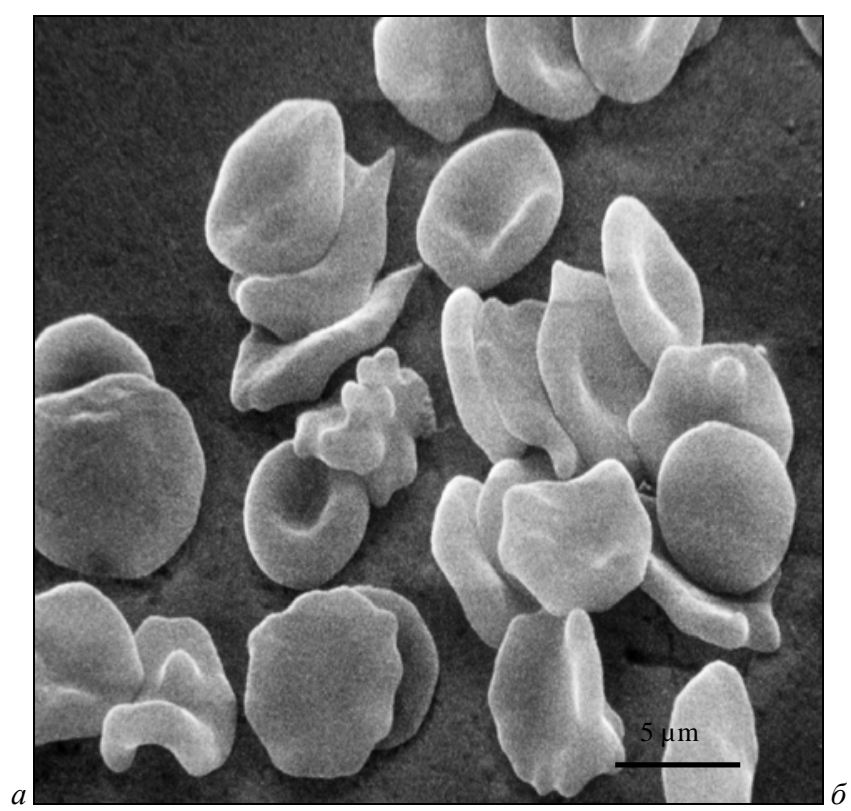



Рис. 6. Гістограма розподілу коефіцієнта форми ядра десквамованих букальних епітеліоцитів (мкм²) у дітей контрольної $(\mathrm{n}=50)$ та основної групи $(\mathrm{n}=50)$

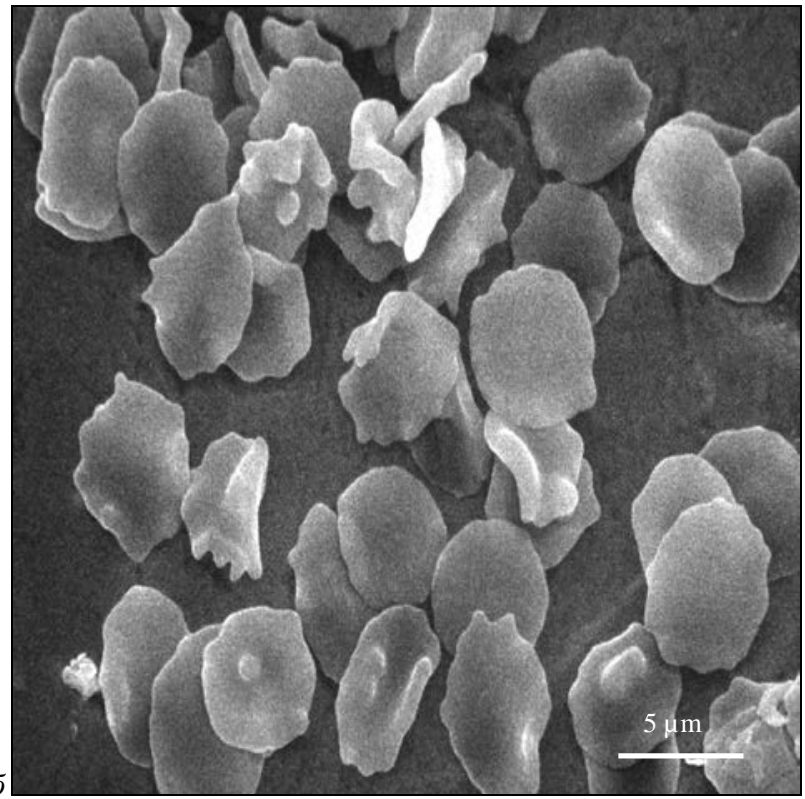

Рис. 7. Зміна форми (a) та розмірів (б) еритроцитів у дітей за психоемоційного стресу: сканувальна електронна мікроскопія

Таблиця

Вміст ферментів антиоксидантної системи, продуктів перекисного окиснення ліпідів та рівень $\mathrm{CD}_{95}{ }^{+}$лімфоцитів в еритроцитах дітей контрольної та основної груп (M $\pm \mathrm{m}, \mathrm{n}=50)$

\begin{tabular}{|c|c|c|c|c|c|}
\hline \multirow[b]{2}{*}{ Група } & \multicolumn{5}{|c|}{ Показники } \\
\hline & $\begin{array}{c}\text { малоновий діальдегід, } \\
\text { нмоль/л }\end{array}$ & $\begin{array}{l}\text { каталаза, } \\
\text { мг } \mathrm{H}_{2} \mathrm{O}_{2} / \text { л }\end{array}$ & $\begin{array}{c}\text { церулоплазмін, } \\
\text { ммоль/л }\end{array}$ & $\begin{array}{c}\text { трансферин, } \\
\text { ммоль/л }\end{array}$ & $\begin{array}{c}\mathrm{CD}_{95}{ }^{+} \text {лімфоцитів, } \\
\text { ум. од. }\end{array}$ \\
\hline Контрольна група & $3,86 \pm 0,02$ & $66,12 \pm 2,48$ & $28,95 \pm 0,81$ & $0,26 \pm 0,002$ & $2,17 \pm 0,23$ \\
\hline Основна група & $6,36 \pm 0,02^{*}$ & $75,44 \pm 3,32 *$ & $10,11 \pm 0,17^{*}$ & $0,19 \pm 0,003^{*}$ & $7,10 \pm 0,33^{*}$ \\
\hline
\end{tabular}

Примітка: * - $\mathrm{P}<0,05$ відносно контрольної групи.

Так само, як й інші автори, ми вважаємо, що під час проведення морфометричного дослідження епітеліоцитів нівелюється вплив суб'єктивних факторів на оцінювання морфологічних змін (Tredoux et al., 2015; Zotti et al., 2016).

Динаміка морфометричних змін площі букальних епітеліоцитів та їх ядер у наших дослідженнях збігається з результатами інших авторів (Moscicka-Studzinska et al., 2009), які визначали морфологічну характеристику організму тварин за психоемоційного стресу за даними змінами в епітеліальних клітинах інших органів.

Виялені нами зміни основних двох показників (малонового діальдегіду та каталази) свідчать про посилення процесів перекисного окиснення ліпідів з утворенням підвищеної кількості вільних радикалів. На фоні змін церулоплазміну та трансфе- рази ці зрушення вказують на погіршення стану AOC3 у дітей за психоемоційного стресу.

На думку Ahmad et al. (2011) i Ellis et al. (2012), збільшення вмісту феритину та заліза на фоні зменшення кількості трансферину у крові відповідає за активність деструктивного процесу за психоемоційного стресу у клітинах усього організму. Це, за даними інших авторів (Bergamini et al., 2004; Karle, 2009; Bianchini et al., 2013), стає можливим за умов здатності цих компонентів до індукції процесів перекисного окиснення ліпідів і ослаблення антиоксидантної системи захисту організму. У сукупності ці фактори створюють на клітинні мембрани системний вплив, що спричиняє втрату їх стійкості до дії вільних радикалів і унеможливлює опір іншим компонентам окисного стресу за таких умов. 
Зважаючи, що еритроцити у сканувальному електронному мікроскопі мають вигляд дискоцита 3 невеликими відхиленнями від округлої форми, що відображено у показнику коефіцієнта їх форми, результати, які ми отримали, свідчать про значні зміни форми еритроцитів за психоемоційного стресу. На думку багатьох авторів (Godin et al., 2009; Reinhart et al., 2009; Ellis et al., 2012), це пов'язано саме з підвищенням процесів перекисного окиснення ліпідів на фоні зниження системи антиоксидантного захисту організму.

Тобто посилення вільнорадикальних реакцій та ослаблення антиоксидантного захисту та змін у букальних епітеліоцитах і еритроцитах периферичної крові пов'язані між собою. Раніше це було показано під час вивчення Морфофункціональних еритроцитів людини та тварин за моделювання різних патологічних станів (Sprague et al., 2010; Ahmad et al., 2011; Swanepoel et al., 2011; Das et al., 2012).



Рис. 8. Кореляційна залежність між показниками антиоксидантної системи та концентрацією продуктів перекисного окиснення ліпідів в основній групі дітей $(\mathrm{n}=50)$ за психоемоційного стресу:

* - вірогідність коефіцієнта кореляції $\mathrm{P}<0,05$

Останніми роками велика увага приділяється апоптозу клітин імунної системи під час психоемоційного стресу (Zhang et al., 2008; Zotti et al., 2016).

Нині апоптоз розглядається як результат дії внутрішньоклітинної генетичної програми незалежно від причини (нормальної або патологічної), що викликала іiі виникнення. Під час апоптозу ядро та цитоплазма піддаються пікнозу, а клітинна оболонка «герметизується» 3 експозицією на зовнішній поверхні ліпідного чинника, що викликає швидкий фагоцитоз макрофагами без розвитку запальної реакції. Ці дані підтверджуються нашими морфометричними знахідками як у букальних епітеліоцитах, так і в еритроцитах периферійної крові.

Ми також підтверджуємо, що апоптоз принципово відрізняється від некрозу, під час якого відбувається набухання та розрив клітин із неминучим розвитком запалення. За таких умов макрофаги не продукують прозапальні цитокіни під час фагоцитозу апоптотичних тілець, проте збільшують продукцію антизапальних цитокінів. Найважливіша ознака апоптозу інтернуклеосомальний розпад ядерної ДНК, що дає можливість виявляти апоптичні клітини in situ за допомогою реакції TUNEL. У розвитку апоптозу ключове значення мають каспази, до субстратів яких відносять життєво важливі білки ядра. Тому виявлені нами морфологчні зміни в ядрі букальних епітеліоцитів можуть опосередковано служити доказом апоптичного сценарію за психоемоційного стресу.

Важливу роль у розвитку апоптозу виконує пошкодження мітохондрій із виходом із них у цитоплазму потужного активатора каспаз - цитохрому С. Це явище пов'язане зі зміною експресії генів родини Bcl-2, що перебувають під контролем гена $\mathrm{p} 53$, активність якого визначає вступ клітини на шлях апоптозу (Sagan et al., 2010). Завершення багатьох імунологічних проце- сів апоптозом зумовлене взаємодією рецептора Fas (CD95/APO-1) i його ліганда FasL, широко розповсюджених у клітинах імунної системи. Цей механізм самостійно або разом із перфорингранзимовим компонентом - головні шляхи цитотоксичного кілінгу, що здійснюється T- і NK-клітинами. Елімінація цих клітин, що вже виконали свою функцію, також відбувається за допомогою FAS-опосередкованого апоптозу (Choi, 2016). Клональна делеція незрілих Т-клітин у вилочковій залозі відбувається без участі Fas/FasL системи. Апоптоз здійснюється під час таких імунологічних реакцій як делеція В-лімфоцитів у гермінтативних центрах за активації антигеном і захист імунопривілейованих органів. За адекватної регуляції апоптозу він підтримує клітинну рівновагу в імунній системі. Ослаблення або посилення темпів апоптозу індукує патологію імунної системи (Gloire et al., 2008).

Наші дані вказують на те, що за психоемоційного стресу у дітей основної групи різко збільшується рівень $\mathrm{CD}_{95}{ }^{+}$лімфоцитів, що свідчить про Fas-залежний апоптоз. Механізми, які зумовлюють гіперекспресію Fas і підвищення рівня апоптозу, пов'язані $з$ розвитком внутрішньоклітинного оксидативного стресу та індукцією монооксигенування у клітинах (Shelton et al., 2013; Sundaramoorthy et al., 2016). За даними цих авторів, за цих умов у різних клітин організму розвиваються морфологічні та морфометричні зміни, подібні до виявлених нами, перебудова структури букальних епітеліоцитів і еритроцитів у дітей основної групи під час психоемоційного стресу.

У зв'язку з викладеним вище ми обрали саме цей віковий контингент дітей, у яких ще досить добре працюють ці механізми у вилочковій залозі, а виявлений нами підвищений рівень $\mathrm{CD}_{95}{ }^{+}$лімфоцитів під час психоемоційного стресу вимагає подальшого дослідження.

Дані, отримані після проведеного кореляційного аналізу між показниками антиоксидантної системи, рівнем продуктів перекисного окиснення ліпідів і рівнем $\mathrm{CD}_{95}{ }^{+}$лімфоцитів, певною мірою узгоджуються з результатами досліджень, отриманими іншими авторами відносно того, що люди з вираженими наслідками психоемоційцної травми мають значно вищий рівень продуктів модифікованого окиснення білків та ліпідів, за вираженого пониження таких антиоксидантних ферментів як супероксиддисмутаза та каталаза, у разі зменшення вмісту відновленого глутатіону на фоні зниження активності глутатіонредуктази та глутатіонпероксидази (Baskevich, 2017).

\section{Висновки}

За психоемоційного стресу виявляються морфологічні зміни букальних епітеліоцитів, які підтвержуються морфометричними показниками і свідчать про зменшення площі робочої поверхні клітин, індукцію апоптозу, що пов'язано з активацією процесів перекисного окиснення ліпідів та пригніченням функціональної здатності антиоксидантної системи захисту організму дітей 7-11 років. Морфометричні зміни еитроцитів периферичної крові, які проявляються зменшенням площі, периметра та різного виду деформаціями, відповідають морфологічним змінам букальних епітеліоцитів, що у поєднанні з різким збільшенням рівня $\mathrm{CD}_{95}{ }^{+}$лімфоцитів свідчить про системний характер змін в організмі дітей під час психоеміційного стресу.

Установлені зміни морфологічного та морфометричного стану букальних епітеліоцитів і еритроцитів свідчать, що в комплексних дослідженнях ці клітини можуть застосовуватись як модельні об'єкти під час установлення системних реакцій організму на вплив різних патологічних факторів.

Запропоновані підходи із застосуванням морфометричних методів у дослідженні букальних епітеліоцитів та еритроцитів із визначенням стану процесів перекисного окиснення ліпідів і антиоксидантної системи захисту - об'єктивне та суттєве доповнення для виявлення ознак психоемоційного стресу та призначення патогенетично обгрунтованої програми медичної реабілітації. 


\section{References}

Ahmad, M. K., Amani, S., \& Mahmood, R. (2011). Potassium bromate causes cell lysis and induces oxidative stress in humanerythrocytes. Environmental Toxicology, 29(2), 138-145.

Baskevich, O. V. (2017). Condition of erythrocyte membranes in people with mental and behavioural disorders caused by alcohol consumption. Regulatory Mechanisms in Biosystems, 8(2), 111-117.

Bergamini, C., Stefania Gambetti, S., Dondi, A., \& Cervellati, C. (2004). Oxygen, reactive oxygen species and tissue damage. Current Pharmaceutical Design, 10(14), 1611-1626.

Bianchini, K., \& Wright, P. A. (2013). Hypoxia delays hematopoaesis: Retention of embryonic hemoglobin and erythrocytes in larval rainbow trout, Oncorhynchus mykiss, during chronic hypoxia exposure. Journal of Experimental Biology, 216(23), 4415-4425.

Choi, J. W. (2016). Fas (CD95/APO-1) associations between soluble APO-1 (Fas/CD95) concentrations and hematopoaetic activity in healthy women. Acta Haematologica, 116(2), 137-140.

Das, D. K., Chakraborty, C. B., Mitra, A. K., Maiti, G. H., \& Ray, A. K. (2012). Quantitative microscopy approach for shape-based erythrocytes characterization in anaemia. Journal of Microscopy, 249(2), 136-149.

Debatin, K.-M. (2009). Sensitivity and resistance - apoptosis in the APO-1 (Fas/CD95) system. Oncology Research and Treatment, 19(1), 3-5.

Ellis, C. G., Milkovich, S., \& Goldman, D. (2012). What is the efficiency of ATP signaling from erythrocytes - regulate distribution of $\mathrm{O}_{2}$ supply within the microvasculature? Microcirculation, 19(5), 440-450.

Gloire, G., Charlier, E., \& Piette, J. (2008). Regulation of CD95/APO-1/Fasinduced apoptosis by protein phosphatases. Biochemical Pharmacology, 76(11), 1451-1458.

Godin, D. V., Gray, G. R., \& Frohlich, J. (2009). Study of erythrocytes in a hereditary hemolytic syndrome (HHS): Comparison with erythrocytes in lecithin:cholesterol acyltransferase (LCAT) deficiency. Scandinavian Journal of Haematology, 24(2), 122-130.

Karle, H. (2009). Destruction of erythrocytes during experimental fever. Acta Medica Scandinavica, 186, 349-359.

Klegarth, A. R. (2017). Buccal swabs. The Intemational Encyclopedia of Primatology, 1-1.

Mishra, R., Dhar, S. S., Mishra, H., \& Asthana, A. K. (2017). Carcinoma buccal mucosa with multiple cutaneous metastases. Annals of International Medical and Dental Research, 3(2), 1-9.
Mortensen, E. (2009). Studies on the osmotic fragility of normal human erythrocytes. Acta Medica Scandinavica, 174(3), 289-297.

Mortensen, E. (2009). Studies on the osmotic fragility of normal human erythrocytes. Acta Medica Scandinavica, 173(6), 693-697.

Moscicka-Studzinska, A., Kijeńska, E., \& Ciach, T. (2009). Electroosmotic flow as a result of buccal iontophoresis - Buccal mucosa properties. European Journal of Pharmaceutics and Biopharmaceutics, 72(3), 595-599.

Nikolovski, D., Dugalic, S., \& Pantic, I. (2017). Iron oxide nanoparticles decrease nuclear fractal dimension of buccal epithelial cells in a timedependent manner. Journal of Microscopy, 1(1), 1-8.

Reinhart, W. H., Zehnder, L., \& Schulzki, T. (2009). Stored erythrocytes have less capacity than normal erythrocytes - support primary haemostasis. Thrombosis and Haemostasis, 101(4), 720-723.

Sagan, D., Jermnim, N., \& Tangvarasittichai, O. (2010). CD 95 is not functiona in human erythrocytes. International Journal of Laboratory Hematology, 32(6), 244-247.

Shelton, R. L., Mattison, S. P., \& Applegate, B. E. (2013). Volumetric imaging of erythrocytes using label-free multiphoton photoacoustic microscopy. Journal of Biophotonics, 7(10), 834-840.

Sprague, R. S., Bowles, E. A., Achilleus, D. M., \& Ellsworth, L. (2010). Erythrocytes as controllers of perfusion distribution in the microvasculature of skeletal muscle. Acta Physiologica, 202(3), 285-292.

Sundaramoorthy, R., Velusamy, Y., Balaji, A. P. B., Mukherjee, A., \& Chandrasekaran, N. (2016). Comparative cytotoxic and genotoxic effects of permethrin and its nanometricform on human erythrocytes and lymphocytes in vitro. Chemico-Biological Interactions, 257, 119-124.

Swanepoel, A. C., \& Pretorius, E. (2011). Scanning electron microscopy analysis of erythrocytes in thromboembolic ischemic stroke. International Journal of Laboratory Hematology, 34(2), 185-191.

Tredoux, S., Mfolozi, S., \& Shires, K. (2015). Efficiency of buccal DNA sampling device in the mortuary. Journal of Forensic Investigation, 3(2), 6.

Zhang, S., Witasp, E., Lauwen, M., \& Fadeel, B. (2008). Brief cross-linking of Fas/APO-1 $\left(\mathrm{CD}_{95}\right)$ triggers engulfment of pre-apoptotic target cells. FEBS Letters, 582, 3501-3508.

Zotti, F. D., Lobysheva, I., \& Balligand, J.-L. (2016). Nitric oxide and hemoglobin form a paramagnetic compound quantifiable by Electron Paramagnetic Resonance (EPR) spectroscopy in venous erythrocytes that reflects vascular NO bioavailability in vivo. Archives of Cardiovascular Diseases Supplements, 8(3), 217. 